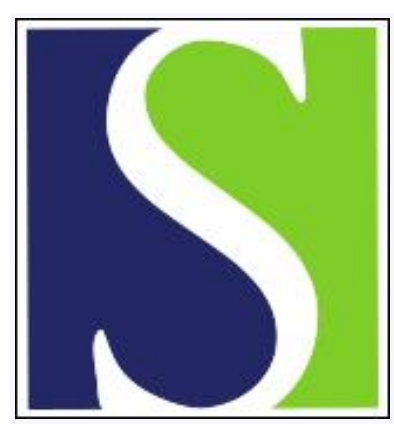

Scand J Work Environ Health 1985;11(2):83-90

https://doi.org/10.5271/sjweh.2249

Issue date: Apr 1985

\title{
Renal toxicity in uranium mill workers.
}

by Thun MJ, Baker DB, Steenland K, Smith AB, Halperin W, Berl T

This article in PubMed: www.ncbi.nlm.nih.gov/pubmed/3890163

\section{(c) (1)}




\title{
Renal toxicity in uranium mill workers
}

\author{
by Michael J Thun, MD, MS, ${ }^{1}$ Dean B Baker, MD, MPH, ${ }^{2}$ Kyle Steenland, MS, ${ }^{1}$
} Alexander B Smith, MD, MS, ${ }^{1}$ William Halperin, MD, MPH, ${ }^{1}$ Thomas Berl, $\mathrm{MD}^{3}$

\begin{abstract}
THUN MJ, BAKER DB, STEENLAND K, SMITH AB, HALPERIN W, BERL T. Renal toxicity in uranium mill workers. Scand J Work Environ Health 11 (1985) 83-90. Although the kidney is the critical organ limiting occupational exposure to soluble uranium compounds, there have been no adequate studies evaluating renal tubular dysfunction in chronically exposed workers. The present investigation evaluated kidney function among 39 uranium mill workers and 36 local cement plant workers of equivalent age, sex, and race. The uranium workers showed a significantly higher excretion of beta2-microglobulin and five amino acids than the reference group. Although the levels of tubular proteinuria were mild, a dose-effect relation existed between the clearance of beta-2-microglobulin, relative to that of creatinine, and the length of time that the uranium workers had spent in the yellowcake drying and packaging area, the work area with the highest exposures to soluble uranium. Age did not account for this relationship. Glomerular function was significantly better among the uranium workers than among the referents, though this may have been the result of differences in the physical activity of the groups during the collection period. The data presented suggest reduced renal proximal tubular reabsorbtion of amino acids and of low molecular weight proteins, consistent with uranium nephrotoxicity.
\end{abstract}

Key terms: beta-2-microglobulin, chemical toxicity, nephrotoxicity, renal effects, SIC 1094 (uranium mining and milling), uranium.

Biologically soluble uranium compounds such as uranyl nitrate $\left[\mathrm{UO}_{2}\left(\mathrm{NO}_{3}\right)_{2}\right]$ and ammonium diuranate $\left(\mathrm{NH}_{3}-\mathrm{UO}_{3}-\mathrm{H}_{2} \mathrm{O}\right)$ are filtered rapidly through the renal glomeruli and are toxic to the renal proximal tubules $(10,27)$. The spectrum of acute toxicity has been studied extensively in animals, and to some extent in man, and includes morphological changes, enzymuria, glycosuria, increased excretion of amino acids and small proteins, and, at higher doses, albuminuria and acute renal failure $(2,10,15,17,27)$.

Much less is known about the chronic effects of long-term occupational exposure. In a study commissioned by the Manhattan Project in the late 1940s, Dounce et al (6) found increased excretion of the tubular enzyme catalase in the urine of 46 chemical workers exposed to uranium, relative to a comparison group. These results were viewed as ambiguous because of uncontrolled differences in urine concentration. Clarkson \& Kench (5) measured urinary amino acid excretion from 18 workers exposed to uranium hexafluoride $\left(\mathrm{UF}_{6}\right)$ and found increased excretion of total amino-nitrogen and individual amino acids among current workers. In general, though, uranium nephrotoxicity has been the subject of relatively little clinical or epidemiologic occupa-

\footnotetext{
1 National Institute for Occupational Safety and Health, Cincinnati, Ohio, the United States.

2 University of California at Los Angeles, School of Public Health, Los Angeles, California, the United States.

${ }^{3}$ University of Colorado, School of Medicine, Denver, Colorado, the United States.
}

Reprint requests to: Dr MJ Thun, National Institute For Occupational Safety and Health, R-16, 4676 Columbia Parkway, Cincinnati, OH 45226, USA. tional research, even though the kidney is considered the critical organ limiting occupational exposure to soluble unenriched uranium (25).

In October 1980 the National Institute for Occupational Safety and Health (NIOSH) was asked by the Oil, Chemical and Atomic Workers International Union and its Local 2-844 to evaluate health effects among workers at a Colorado uranium mill. Until mid-1979, workers in one area of the mill had been exposed to air concentrations of uranium dust exceeding the current occupational standard for soluble uranium (25). The uranium was present as a dry concentrate called "yellowcake," a powder containing salts and oxides of natural uranium. Although yellowcake is chemically complex, it contains $26-86 \%$ ammonium diuranate, which has traditionally been regarded as biologically soluble (7).

The present cross-sectional study was conducted to determine whether workers with prolonged exposure to soluble uranium (yellowcake) had detectable tubular or glomerular dysfunction. Since the primary renal lesion of uranium is tubular, we were particularly interested in whether tubular reabsorption of amino acids or beta-2-microglobulin (beta-2) would be impaired in workers with long-term exposure.

\section{Background}

The mill under study has processed uranium ore since 1958. Raw ore containing natural uranium is first crushed and then leached with acid to extract the uranium salts. The natural uranium in the crushing area has low biological solubility. Exposure to dust 
containing soluble uranium occurs primarily after the ore has been leached and the uranium precipitated and dryed in the "yellowcake" drying and packaging area. Some industrial hygiene data are available on exposure since 1975 . In 1975-1979, monthly average air measurements of total uranium in the yellowcake drying and packaging area exceeded, by up to eightfold, the occupational standard of $1 \times 10^{-10} \mu \mathrm{Ci} / \mathrm{ml}$ (3.7 Bq/m $\mathrm{m}^{3}$ ) (25). Similarly, assays for urinary uranium (table 1) showed that in 1975-1978, 115 of 535 $(21 \%)$ measurements of uranium in urine exceeded the upper action level of $30 \mu \mathrm{g} / 1$ (126 nmol/1) recommended by the United States (US) Nuclear Regulatory Commission (NRC) (26). This action level, based on toxicologic data (22), is reported to be the concentration in urine above which kidney damage can occur. Both dust exposures and the concentrations of uranium in the urine declined in mid-1979, when a new mill facility was completed. Subsequent measurements have been generally within legal or recommended limits.

\section{Subjects and methods}

To select the study group, we used personnel records, seniority lists, and employee committees to identify workers with past exposure to yellowcake. These included 27 workers with at least one year of exposure in the yellowcake area of the old mill, and three employees hired after the new mill became operational and presently working in the yellowcake area. In addition 12 senior employees were included who had always worked in the crushing area. Exposures in the crushing area are to less soluble compounds of uranium. Thirty-nine of the 42 uranium workers identified agreed to participate. Workers at a nearby cement production plant participated as an external comparison group. We selected these workers by first identifying three potential candidates, matched for race, sex, and age ( \pm two years), for each exposed subject from a complete roster of cement production workers. To contact these candidates, we attended

Table 1. Urine uranium levels in exposed workers ${ }^{a}-1975-$ 1981.

\begin{tabular}{lccccc}
\hline Year & $\begin{array}{c}\text { Number } \\
\text { of } \\
\text { samples }\end{array}$ & Mean & Median & $\begin{array}{c}\text { Percentiles } \\
\text { 5th-95th }\end{array}$ & $\begin{array}{c}\text { Exceeding } \\
\text { action } \\
\text { level(\%) }\end{array}$ \\
\hline 1975 & 115 & 65.2 & 20 & $7.0-120$ & 39.1 \\
1976 & 141 & 18.9 & 8 & $2.5-92$ & 19.9 \\
1977 & 154 & 20.5 & 7 & $2.5-70$ & 20.8 \\
1978 & 125 & 19.1 & 5 & $2.5-47$ & 8.0 \\
1979 & 887 & 12.2 & 6 & $4.0-37$ & 2.7 \\
1980 & 904 & 9.1 & 5 & $4.0-15$ & 1.5 \\
$1981^{c}$ & 377 & 7.2 & 6 & $4.0-14$ & 0.0 \\
\hline
\end{tabular}

a Results are in micrograms of uranium per liter of urine (1 $\mu \mathrm{g} / \mathrm{l}=1 \mu \mathrm{mol} \times 238$ ). The "action level" is $30 \mu \mathrm{g} / \mathrm{l}$.

b The 5th and 95th percentiles are presented to minimize distortion due to contaminated samples. In 1979 the lower

limit of detection changed from 2.5 to $4.0 \mu \mathrm{g} / \mathrm{l}$.

c Data for 1981 include only January through July. routine safety conferences and encouraged participation in the study. We contacted and recruited 43 of the 44 present on the days of our visits, approximately one-third of the total workforce. Subsequently we excluded seven who had had prior employment at the uranium mill. Thirty-six remained, of whom 33 completed matched pairs, while three others were duplicates. Thus the study populations included 39 uranium-exposed workers and 36 referents (unmatched analysis), and 33 pairs (matched-pair analysis).

To assess renal function, we collected an 8-h urine sample on each worker over the workday and drew midshift blood samples. Aliquots of urine were adjusted to a $\mathrm{pH}$ above 5.5, refrigerated for transport, and frozen at $-70^{\circ} \mathrm{C}$ on arrival at the laboratory. Measurement of serum and urine beta- 2 was by Phadebas ${ }^{\circledR}$ radioimmunoassay (8). Serum and urine creatinine were measured by an autoanalyzer, using the modification of the Jaffe method (Technicon Instruments, SE4-0011FH4, Tarrytown, NY, USA 1974). The concentrations of 26 amino acids were measured in the urine by ion-exchange chromatography on a Beckman 121-M amino acid analyzer, using a 5-buffer lithium citrate system. Samples were deproteinized with salicylic acid prior to the analysis, and norleucine was added as an internal standard. The analyses followed standard instrument procedure (Beckman Chromatography, 2500 Harbor Blvd, Fullerton, CA 92634, USA).

Serum creatinine and creatinine clearance were used as markers of glomerular function. Clearance was calculated using the formula: clearance $=$ urine concentration $\times$ urine output (in milliliters per minute)/ plasma concentration. Creatinine clearance was standardized to a body surface area of $1.73 \mathrm{~m}^{2}$ based upon height and weight information and a standard surface area nomogram (9).

We measured the renal excretion of beta- 2 and of individual and grouped amino acids as indicators of decreased tubular reabsorption of low-molecular weight proteins $(1,16)$. To adjust for glomerular function, we computed the ratio of beta- 2 clearance to creatinine clearance. This ratio, called the fractional excretion of beta-2, most closely reflects the tubular component of beta-2 excretion. Amino acid excretion was standardized for both urinary creatinine concentration (nanomoles per mole of creatinine) and for minutes of collection (nanomoles per minute). These methods of standardization yielded equivalent results, and in this report we present only the correction for creatinine. Three of the 26 amino acids measured were excluded from the analysis. They were proline, which was below the level of detection for all subjects, and 1- and 3-methylhistidine which are known to vary substantially with diet (20).

Detailed employment records were not available. We obtained questionnaire data on jobs held at the uranium mill and on exposure to extraneous nephro- 
toxins such as lead, cadmium, phenacetin or related analgesics, and aminoglycoside antibiotics. We inquired about known personal or familial renal, prostatic, hypertensive, or diabetic disease. We also measured blood pressure and determined the blood lead and cadmium concentrations by anodic stripping voltammetry (14).

To determine the statistical significance of the differences between the exposed and unexposed groups, we used the chi-square test for dichotomous variables, and matched and unmatched Student's t-tests for continuous variables. Within the uranium group, we also used multiple regression analysis to test which exposure variables best predicted the fractional excretion of beta-2. A two-sided alpha level of 0.05 was used as the criterion for statistical significance.

In presenting the data on beta-2 and amino acid excretion, we show only the unmatched analysis of the entire study population. Results of the matched analysis are noted in the text only where the statistical significance differed from that of the unmatched analysis. In general, the statistical significance of the two analyses were nearly identical.

To compare excretion of a number of physiologically linked amino acids, we also grouped the amino acids according to known transport systems (table 2) (21). These transport systems have been characterized from various genetic disorders of membrane transport such as cystinuria and Hartnup disease. Although some amino acids, such as cystine, may be absorbed by more than one transport system, the grouping provides a way of dealing with linked amino acids. We used a multivariate analysis of variance, with the Hotelling's t-test (13), to test whether excretion of the grouped amino acids was significantly different between the exposed and unexposed. Statistical analytic system (SAS) programs were used for all the statistics.

\section{Results}

\section{Population characteristics}

The study and reference populations were similar. Both groups consisted of white male Colorado residents from neighboring towns. The age, work histories, mean blood lead, and mean blood cadmium levels of the two groups are presented in table 3.

Assessment of nephrotoxic exposures other than uranium showed a small but statistically significant elevation of blood lead in the referents as compared to the exposed. The highest blood lead value among the referents was $36 \mu \mathrm{g} / 100 \mathrm{cc}(1.74 \mu \mathrm{mol} / \mathrm{l})$, the next highest value being $24 \mu \mathrm{g} / 100 \mathrm{cc}(1.16 \mu \mathrm{mol} / \mathrm{l})$. The difference between the groups was not explained by activities involving known lead exposure as reported on the questionnaire. The blood cadmium levels did not differ significantly between the groups.

\section{Renal function}

Since most of the parameters measured serve to evaluate more than one aspect of renal function, we present the results as they pertain to tubular function, glomerular function, or extrarenal effects.

Table 2. Grouping of amino acids according to known transport systems (21).

\begin{tabular}{|c|c|c|c|c|}
\hline Iminoglycine group & Neutral group & Dicarboxylic group & Dibasic group & Nonalpha group \\
\hline Glycine & $\begin{array}{l}\text { Glutamine } \\
\text { Histidine } \\
\text { Serine } \\
\text { Threonine } \\
\text { Phenylalanine } \\
\text { Tyrosine } \\
\text { Alanine } \\
\text { Aminobutyric } \\
\text { Valine } \\
\text { Methionine } \\
\text { Isoleucine } \\
\text { Leucine } \\
\text { Cystathionine } \\
\text { Citrulline }\end{array}$ & $\begin{array}{l}\text { Aspartic acid } \\
\text { Giumatic acid } \\
\text { Alpha-aminoadipic acid }\end{array}$ & $\begin{array}{l}\text { Cystine } \\
\text { Lysine } \\
\text { Ornithine } \\
\text { Arginine }\end{array}$ & Taurine \\
\hline
\end{tabular}

Table 3. Characteristics of the uranium exposed and comparison groups - Unmatched data.

\begin{tabular}{|c|c|c|c|c|c|c|c|}
\hline \multirow{2}{*}{ Characteristic } & \multicolumn{3}{|c|}{ Exposed $(\mathrm{N}=39)$} & \multicolumn{3}{|c|}{ Unexposed $(\mathrm{N}=36)$} & \multirow[b]{2}{*}{$p-$ Value $^{a}$} \\
\hline & Mean & SD & Range & Mean & SD & Range & \\
\hline $\begin{array}{l}\text { Age (years) } \\
\text { Employment in uranium mill (years) } \\
\text { Blood lead }(\mu \mathrm{mol} / \mathrm{l}) \\
\text { Blood cadmium (nmol/l) }\end{array}$ & $\begin{array}{l}43.7 \\
10.3 \\
0.45 \\
31.2\end{array}$ & $\begin{array}{c}10.6 \\
5.8 \\
0.14 \\
24.6\end{array}$ & $\begin{array}{r}26.5-64.5 \\
1.1-22.6 \\
0.14-0.82 \\
13.3-83.6\end{array}$ & $\begin{array}{l}42.0 \\
\overline{0.78} \\
24.7\end{array}$ & $\begin{array}{l}10.2 \\
. \\
0.27 \\
17.5\end{array}$ & $\begin{array}{l}26.7-59.8 \\
0.29-1.74 \\
13.3-80.1\end{array}$ & $\begin{array}{l}\text { NS } \\
0.0001 \\
\text { NS }\end{array}$ \\
\hline
\end{tabular}

a Level of significance calculated by Student's t-test. NS = probability greater than 0.05 . 
Table 4. Renal function in the uranium exposed and unexposed groups - Unmatched analysis.

\begin{tabular}{|c|c|c|c|c|c|c|c|}
\hline \multirow{2}{*}{ Variable } & \multicolumn{3}{|c|}{ Exposed $(\mathrm{N}=39)$} & \multicolumn{3}{|c|}{ Unexposed $(\mathrm{N}=36)$} & \multirow{2}{*}{$\begin{array}{l}\text { Level of } \\
\text { significance }\end{array}$} \\
\hline & Mean & SD & Range & Mean & SD & Range & \\
\hline \multicolumn{8}{|l|}{ Beta-2-microglobulin b } \\
\hline $\begin{array}{l}\text { Serum }(\mu \mathrm{g} / \mathrm{ml}) \\
\text { Urine }(\mu \mathrm{g} / \mathrm{l}) \\
\text { Urine }(\mu \mathrm{g} / \mathrm{h}) \\
\text { Urine }(\mathrm{mg} / \mathrm{g} \text { creatinine) } \\
\text { Clearance }(\mathrm{ml} / \mathrm{min})\end{array}$ & $\begin{array}{c}2.05 \\
54.9 \\
4.40 \\
0.060 \\
0.038\end{array}$ & $\begin{array}{c}0.46 \\
38.7 \\
2.99 \\
0.38 \\
0.27\end{array}$ & $\begin{array}{c}1.28-3.40 \\
4.0-140.0 \\
0.36-13.63 \\
0.004-0.189 \\
0.002-0.116\end{array}$ & $\begin{array}{l}1.83 \\
37.6 \\
2.50 \\
0.036 \\
0.023\end{array}$ & $\begin{array}{l}0.26 \\
39.2 \\
2.05 \\
0.031 \\
0.019\end{array}$ & $\begin{array}{c}1.36-2.40 \\
1.0-170.0 \\
0.18-10.01 \\
0.002-0.164 \\
0.002-0.087\end{array}$ & $\begin{array}{l}0.01 \\
0.06 \\
0.002 \\
0.004 \\
0.01\end{array}$ \\
\hline \multicolumn{8}{|l|}{ Creatinine $^{c}$} \\
\hline $\begin{array}{l}\text { Serum }(\mathrm{mg} / 100 \mathrm{cc}) \\
\text { Urine }(\mathrm{mg} / 100 \mathrm{ccc}) \\
\text { Clearance }(\mathrm{ml} / \mathrm{min})^{d}\end{array}$ & $\begin{array}{c}1.15 \\
102.9 \\
95.6\end{array}$ & $\begin{array}{l}0.15 \\
62.6 \\
20.6\end{array}$ & $\begin{array}{l}0.92-1.74 \\
23.1-285.2 \\
48.8-172.2\end{array}$ & $\begin{array}{c}1.22 \\
114.6 \\
88.4\end{array}$ & $\begin{array}{l}0.11 \\
63.5 \\
13.0\end{array}$ & $\begin{array}{l}0.91-1.40 \\
11.4-259.6 \\
39.1-116.6\end{array}$ & $\begin{array}{l}0.02 \\
0.42 \\
0.08\end{array}$ \\
\hline Relative clearance ${ }^{e}$ & 3.95 & 2.64 & $0.23-11.19$ & 2.62 & 2.17 & $0.18-10.71$ & 0.02 \\
\hline
\end{tabular}

a Level of significance calculated by Student's t-test for unmatched analysis.

b $1 \mu \mathrm{g}$ beta-2-microglobulin $=1 \mu \mathrm{mol} \times 11600$.

c $1 \mathrm{mg}$ creatinine $=1 \mathrm{mmol} \times 113.12$.

d Creatinine clearance standardized to a body surface area of $1.73 \mathrm{~m}^{2}$.

e Beta-2-microglobulin clearance $\times 10^{4}$ /creatinine clearance.

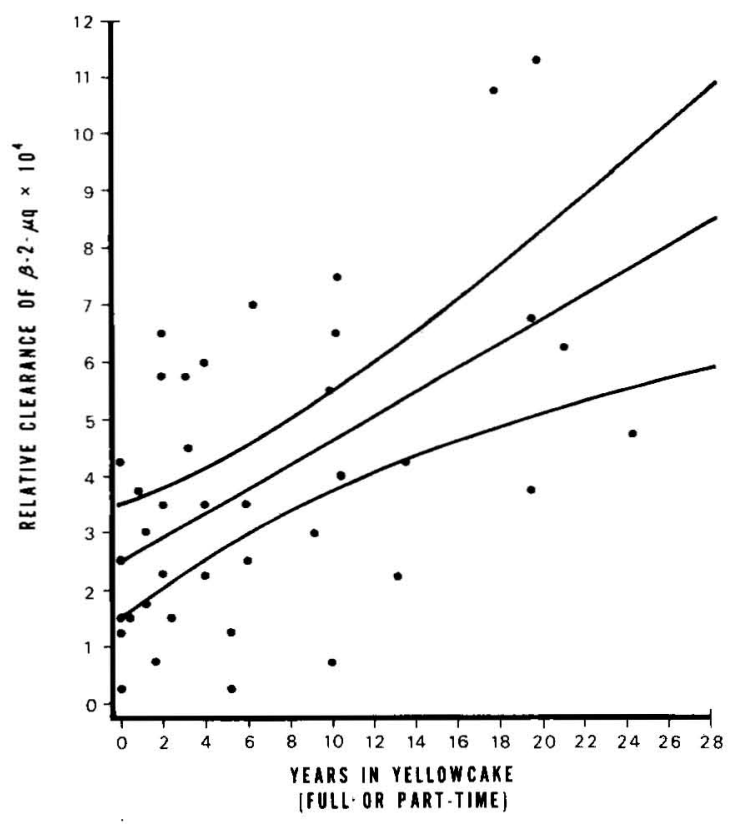

Figure 1. Clearance of beta-2-microglobulin relative to creatinine clearance versus years in the yellowcake area of the old mill (full- or part-time).

\section{Tubular function}

Table 4 presents the data on beta- 2 excretion among the uranium workers and the referents. The excretion of beta- 2 was significantly higher among the uranium workers when expressed in a variety of ways, including clearance and clearance relative to creatinine clearance. The urine concentration of beta- 2 was not significantly different between the groups, nor did the urinary beta- 2 concentration of any worker exceed the upper limit of normal, cited by the test manufacturer, of $370 \mu \mathrm{g} / \mathrm{l}(32 \mathrm{nmol} / \mathrm{l})(8)$.
Within the uranium-exposed group, the variable which best predicted the beta- 2 clearance relative to creatinine clearance was the length of time an employee had worked full-time in the yellowcake area of the old mill. This variable alone explained $17 \%$ of the variance of the fractional excretion of beta-2 $\left(R^{2}=0.17, p=0.009\right)$. Age did not contribute significantly to the regression model, nor did it eliminate the statistical significance of yellowcake exposure. Of the other variables tested, such as blood cadmium, lead, height, weight, blood pressure, and other jobs, only the length of time that an employee had worked in the job "shifting" contributed significantly. This job involved part-time employment in the yellowcake area. Together full- and part-time yellowcake exposure explained $30.5 \%$ of the variance $(p=0.001)$. Because of the small number of workers with prolonged full-time work in the yellowcake area and because the slopes of the separate regression lines for full- and part-time yellowcake exposure were similar $\left(2.28 \times 10^{-4}\right.$ vs $\left.1.94 \times 10^{-4}\right)$, we combined these two variables (figure 1). The slope of the regression for this combined variable was highly significant $(p=0.0003)$. The upward slope remained significant $(p=0.01)$ even when the two uranium workers whose relative clearance of beta- 2 exceeded $10 \mu \mathrm{g} \times 10^{-4}$ were excluded. There is no sound reason for excluding these two individuals, however, and we present the full data.

The mean amino acid excretion, adjusted for creatinine, was higher among the uranium workers than the referents for 22 of the 23 amino acids compared. Citrulline was the only exception. The differences in the levels of excretion were mild and were statistically significant only for methionine, cystathionine, ornithine, aspartic acid, and arginine. The comparison data for these five amino acids are listed in table 5.

In analyzing the grouped amino acids, we excluded the nonalpha and iminoglycine groups, since these 
Table 5. Amino acid excretion in uranium exposed and comparison groups - Unmatched analysis. ${ }^{a}$

\begin{tabular}{|c|c|c|c|c|c|}
\hline \multirow{2}{*}{ Amino acid } & \multicolumn{2}{|c|}{ Exposed } & \multicolumn{2}{|c|}{ Unexposed } & \multirow{2}{*}{$\begin{array}{c}\text { Level of } \\
\text { significance }\end{array}$} \\
\hline & Mean & $\mathrm{SD}$ & Mean & $\mathrm{SD}$ & \\
\hline $\begin{array}{l}\text { Methionine } \\
\text { Cystathionine } \\
\text { Ornithine } \\
\text { Aspartic acid } \\
\text { Arginine }\end{array}$ & $\begin{array}{l}0.32 \\
0.14 \\
0.12 \\
1.48 \\
0.06\end{array}$ & $\begin{array}{l}0.14 \\
0.07 \\
0.08 \\
0.41 \\
0.06\end{array}$ & $\begin{array}{l}0.20 \\
0.10 \\
0.09 \\
1.24 \\
0.03\end{array}$ & $\begin{array}{l}0.10 \\
0.06 \\
0.05 \\
0.52 \\
0.02\end{array}$ & $\begin{array}{l}0.0001 \\
0.02 \\
0.03 \\
0.03 \\
0.04\end{array}$ \\
\hline
\end{tabular}

a Results are in nanomoles per mole of creatinine.

b Level of significance calculated by Student's t-test.

contained only one amino acid each. For these two amino acids, taurine and glycine, respectively, the previous comparison had shown that the uranium workers excreted more than the reference group, but that the difference was not statistically significant. The excretion of grouped amino acids was examined for the dibasic, neutral, and dicarboxylic groups to determine whether certain amino acid transport systems were impaired. A statistically greater excretion of dicarboxylic $(p=0.03)$ and neutral $(p=0.008)$, but not dibasic, amino acids was observed among the uranium workers. Within the neutral group it is possible to distinguish a methionine subgroup composed of methionine, phenylalanine, tyrosine, leucine, and isoleucine (20). The increased excretion was apparently limited to this methionine subgroup. When the neutral group was reanalyzed without the methionine subgroup, the difference between the exposed and unexposed workers became statistically nonsignificant.

\section{Glomerular function}

Table 4 also presents the data on serum creatinine and creatinine clearance. In both groups the serum creatinine levels were normal, whereas the creatinine clearances were slightly low compared to those of published reference populations (18). In the unmatched analysis, the reference group showed a significantly higher mean serum creatinine and a lower mean creatinine clearance. The difference between the creatinine clearances of the two groups was statistically significant only in the matched analysis $(p=0.04)$. The lower glomerular function among the referents was not explained by associated diabetic, prostatic, hypertensive, or other renal disease. Rather, the variable which most closely correlated with creatinine clearance within the reference group was blood lead $(R=0.32, p=0.057)$. The significance of this finding is unclear, since the blood lead concentrations were relatively low.

\section{Extrarenal effects}

The serum concentration of beta- 2 was significantly higher among the uranium workers. Nine $(23 \%)$ uranium workers, and only two $(5.6 \%)$ of the referents, had serum beta- 2 levels which equaled or ex- ceeded the upper level of normal $(2.4 \mu \mathrm{g} / \mathrm{ml}$ or 206.9 $\mathrm{nmol} / \mathrm{l}$ for males under 50 years of age) (8). The increased serum levels of the nine exposed were not explained by reduced glomerular function since their serum creatinine and creatinine clearance measurements were equivalent to those of their age-matched referents. Nor did the presence of high serum levels in this subgroup of uranium workers account for the increased urinary excretion in the overall group, since the average beta- 2 excretion of these workers $(2.33$ $\mu \mathrm{g} / \mathrm{h}$ ) was below the average of the reference group $(2.50 \mu \mathrm{g} / \mathrm{h})$.

When analyzed by multiple regression analysis, no variables predicted serum beta- 2 levels among the exposed at a statistically significant level. However, the variable representing years of employment in the crushing area of the mill, exposed to insoluble uranium, was nearly significant $\left(R^{2}=0.07, p=0.10\right)$ as was the negative association with urine output per minute $\left(\mathrm{R}^{2}=0.07, \mathrm{p}=0.09\right)$.

\section{Discussion and interpretation}

The present study demonstrates low-level beta-2-microglobulinuria and aminoaciduria among current uranium mill workers, relative to a local occupational comparison group. Although the levels of tubular proteinuria were well below those observed in acquired Fanconi syndrome, a dose-effect relation existed between the clearance of beta-2, relative to creatinine, and the length of time that the uranium workers had spent in the mill area involving the highest exposure to soluble uranium. This relationship was not explained by age or by the other variables measured.

Three separate issues are involved in the interpretation of these findings. First is the question of whether the results can be explained by factors unrelated to the renal effects of uranium, such as differences in the collection or preservation of the urine samples. Second, if the results do appear to represent a real difference in renal function between the groups, what is their physiological and clinical significance, and, third, what implications do they hold for the current regulations limiting occupational exposure to uranium? 
Because the observed level of tubular proteinuria was mild, the possibility that the findings may be artifactual should be given serious consideration. If, for example, the comparison workers excreted urine that was more acidic than the exposed, then the lower bladder $\mathrm{pH}$ could cause accelerated hydrolysis of beta-2 in the urine (12). Hydrolysis occurring in the bladder would not be prevented by the alkalinization of samples at the time of collection, and it could explain an artifactually low beta- 2 concentration among the unexposed workers by causing that of the exposed workers to appear high. We could not evaluate differences in urine acidity between the groups. Although we measured the $\mathrm{pH}$ of the urine samples, we did so only to alkalinize those samples with a $\mathrm{pH}$ below 5.5 and did not record the data. Even though a difference in average urine acidity between groups is theoretically possible, such an occurrence would not explain all of the study findings. First, it would not explain the aminoaciduria observed among the uranium workers, since amino acids are not similarly hydrolyzed. Second, it would not account for the dose-effect relation observed between length of uranium exposure and beta-2-microglobulinuria. Third, unless one postulates the existence of renal tubular acidosis as the underlying physiological defect caused by uranium, there is no plausible biological reason why the cement workers should excrete more acidic urine than the uranium workers. Cement dust is intensely alkaline. If absorbed, it would raise rather than lower the $\mathrm{pH}$ of the cement worker's urine.

Beta-2 metabolism is complex, as it involves a balance between production and catabolism or elimination. Biosynthesis occurs in almost all human cells. Increased production of beta-2, with elevated serum levels, has been observed in a number of neoplastic and immunologic disorders such as lymphocytic and monocytic leukemia, multiple myeloma, carcinomas, sarcoidosis, Sjogren's syndrome, and systemic lupus erythematosis $(1,16)$. Increased production may also be a feature of chronic cadmium poisoning (11). Renal excretion of beta- 2 involves filtration through the glomeruli and uptake and catabolism by the proximal tubular cells (16). Damage to the proximal tubules due to heavy metals or toxic substances such as cadmium, mercury, or aminoglycoside antibiotics causes beta- 2 to be excreted intact in the urine $(3,8$, $11,19)$. Thus urinary excretion usually reflects decreased tubular reabsorbtion, whereas increased serum beta-2 may reflect either increased production or decreased glomerular filtration.

The mechanism of beta-2-microglobulinuria among the uranium workers in our study apparently involves both increased production and decreased renal tubular reabsorption. Serum beta-2 levels were significantly higher among the exposed, despite evidence that the glomerular clearance of beta- 2 and creatinine exceeded that of the referents. Such a pattern is consistent with increased production. Since serum beta-2 was associated with length of exposure to insoluble uranium in the crushing area of the mill, it may be that insoluble uranium, like cadmium, stimulates production of beta- 2 in ways that are not presently understood. Renal tubular excretion of beta-2 was also significantly higher among the uranium workers and therefore suggests impaired tubular reabsorption. Increased renal excretion was associated with length of exposure to soluble uranium, consistent with uranium-induced nephrotoxicity.

The clinical significance of low-level aminoaciduria and beta-2-microglobulinuria is unclear. Beta-2 has not been measured previously in uranium workers, and only one previous study has measured urine amino acids in persons chronically exposed to uranium (5). Clarkson \& Kench found low but significantly elevated levels of amino acids in the urine of 12 workers exposed to uranium hexafluoride. In both the Clarkson \& Kench study and our study, the aminoaciduria was generalized, certain amino acids showing the greatest increase in excretion. The transport systems the most affected in our study were those of the dicarboxylic amino acids and of the methionine subgroup of the neutral amino acids. It may be that different amino acid transport systems are susceptible in varying degrees to damage from uranium or that, following injury, different transport systems recover at different rates.

Since we did not measure serum amino acids, one could argue that the aminoaciduria exhibited by the exposed workers might derive from increased intake or impaired catabolism rather than from decreased tubular reabsorption. Increased dietary intake is unlikely because the groups were culturally similar and because the uranium workers were more sedentary. We know of no example of increased production or impaired degradation that involves multiple amino acids.

An unanswered question is whether the measurements of serum creatinine and creatinine clearance also suggest decreased glomerular function among the uranium-exposed workers or the referents. Although the glomerular function of the exposed workers exceeded that of the referents, we urge caution in interpreting these results. The observed differences may have been an artifact of the more strenuous physical exertion required by the jobs of the cement workers. The uranium workers were mostly machine operators, whereas many of the cement workers were laborers. Disparities in physical exertion affect muscle breakdown, renal blood flow, and protein intake. In our opinion, the measures of glomerular function, and particularly of creatinine clearance, are more useful for standardizing beta-2 clearance for glomerular filtration rate than for their absolute value in assessing renal function.

Similarly the measurements of serum creatinine and creatinine clearance are not directly comparable to published values for the general population. Mea- 
surements made during an 8-h workday under field conditions differ substantially from measurements made over $24 \mathrm{~h}$ upon sedentary or hospitalized subjects. In addition the autoanalyzer uses a modified Jaffe technique to measure creatinine concentration in serum and urine. The Jaffe method measures total chromogens and may overestimate the concentration of true creatinine by $25 \%$ or more (18). Although the data are comparable internally, they cannot be compared reliably to population reference values based on true creatinine values.

Despite the caveats discussed, the study is more likely to have under- than overestimated the severity of uranium-induced nephropathy. First, the crosssectional design could have missed workers with clinical renal disease who left work because of health. The reason for terminating employment was not recorded in a worker's personnel file. Second, since none of the uranium workers had been exposed to air concentrations of soluble uranium above the present standard for two years prior to the medical study, the study could have underestimated reversible renal effects. Third, exposures were relatively short. Only one of the uranium workers had worked full-time in the yellowcake area for 20 years, and only two others for over 10 years. The severe renal tubular disease seen in workers exposed to heavy metals such as cadmium usually appears following prolonged exposure of 20 years or more.

The occupational significance of this study is twofold. First, it provides supplemental evidence that the renal effects of chronic occupational exposure to soluble uranium should not be ignored. The results of our investigation, those of the Clarkson \& Kench study, and case reports describing transient albuminuria in workers acutely overexposed to soluble uranium suggest that occupational exposures can and do exceed the "no-effect" level $(4,5)$. Also of concern is the epidemiologic finding of a 2.6-fold excess in deaths from chronic and unspecified nephritis and renal sclerosis (International Classification of Diseases, seventh revision, 592-594) in a retrospective study of mortality among a cohort of US white male uranium miners. (28). Eight deaths from chronic renal disease were observed among the miners, whereas 3.1 were expected from the US general population (95\% confidence limits 113-516). The increased mortality among the miners may have resulted from some other potentially nephrotoxic exposure in the mines rather than from the relatively insoluble uranium oxides, yet these findings are cause for concern (23).

The second implication of our study is that the assumptions underlying the current occupational standard for soluble uranium in air and for uranium in urine should be carefully scrutinized. The nephrotoxicity of soluble uranium compounds is well recognized and provides the basis for the current occupational standard. The uranium standard was originally based upon extensive, quantitative toxico- logic data collected on both man and animals by researchers involved in the Manhattan Project in the 1940s (27). It has been said that the Manhattan Project toxicologic research was "conducted on a scale that is probably unequalled in the history of toxicology [p 245]" (22). Although the original recommendation for a maximum permissible concentration in air $\left(\mathrm{MPC}_{\mathrm{a}}\right)$ was $50 \mu \mathrm{g} / \mathrm{m}^{3}$, based upon a "noeffect" level for the kidney, it was later changed to an $\mathrm{MPC}_{\mathrm{a}}$ of $200 \mu \mathrm{g} / \mathrm{m}^{3}$. The more lenient standard, which is in use today, was justified by "the lack of evidence following 25 years of industrial experience of any definite association between exposure to higher levels of airborne uranium and injury either to the kidney or to the blood [p 249]' (22). Yet to our knowledge, no epidemiologic studies have systematically evaluated renal tubular function in uranium workers, nor has routine medical monitoring been conducted using sensitive measures of tubular function. The only medical monitoring that is required is measurement of qualitative urine albumin following instances of acute overexposure (26). The dipstick measurement of urine albumin is, however, an insensitive test for renal tubular injury.

Certain of the recommendations and guidelines regarding the biological monitoring of uranium in urine are also at variance with the threshold concentrations observed in the early toxicologic studies. The NRC draft regulatory guideline, based upon the Manhattan Project data and intended for use by uranium mills, considers $30 \mu \mathrm{g} / \mathrm{l}(126 \mathrm{nmol} / \mathrm{l})$ to be the concentration of uranium in urine which is potentially nephrotoxic. The NRC requires work restrictions following a single confirmed sample at that level. Certain state licensing programs, however, allow higher action limits to be used by mills and other uranium facilities. The official document of the US Air Force (24) advises an end-week limit of $100 \mu \mathrm{g} / 1$ (420 $\mathrm{nmol} / \mathrm{l})$ and states that $100-250 \mu \mathrm{g} / 1(420-1050$ nmol/l) is "probably safe." Our data would suggest that urine levels should be kept within the NRC guidelines.

In summary, the study found low-level beta-2microglobulinuria and aminoaciduria in workers exposed to soluble uranium compounds. The implications of this finding, in light of past research on uranium and current occupational controls, are discussed.

\section{Acknowledgments}

The authors wish to thank Mr K Anderson and Drs W Greaves and T Thoburn for their assistance in the field investigation. We are indebted to Dr S Goodman for measuring the amino acids and for adivising us about these data. We thank Drs P Strudler, E Avner, F Epstein, and M Goldberg for their technical aid and clinical guidance during the preparation of the manuscript. 
Note: Reference to brand names is for identification purposes only and does not constitute endorsement by the US Public Health Service.

\section{References}

1. Anderson NG, Anderson NL, Tollaksen SL. Proteins of human urine: 1 . Concentration and analysis by two dimensional electrophoresis. Clin Chem 25 (1979): 7, 1199-1210.

2. Blantz R. The mechanism of acute renal failure after uranyl nitrate. J Clin Invest 55 (1975) 621-635.

3. Buchet JP, Roels H, Bernard A, Lauwerys R. Assessment of renal function of workers exposed to inorganic lead, cadmium, and mercury vapor. J Occup Med 22 (1980) $741-750$.

4. Butterworth A. Human data of uranium exposure. US Atomic Energy Commission, Washington, DC 1979, pp 41-46. (USAEC report HASL-58).

5. Clarkson TW, Kench JE. Urinary excretion of amino acids by men absorbing heavy metals. Biochem J 62 (1952) $361-371$.

6. Dounce AL, Roberts E, Wills JH. Catalasuria as a sensitive test for uranium poisoning. In: Voegtlin $\mathrm{C}$, Hodge HC, ed. Pharmacology and toxicology of uranium compounds. Volume 1. McGraw Hill, New York, NY 1949, pp 889-950.

7. Eidson AF, McWhinney JA. In vitro solubility of yellowcake samples from four uranium mills and the implications for bioassay interpretation. Health Phys 39 (1980) 893-902.

8. Evrin P, Wibell L. The serum levels and urinary excretion of beta-2-microglobulin in apparently healthy subjects. Scand J Clin Lab Invest 29 (1972) 69-74.

9. Hamburger J, Richet G, Crosnier J, Funck-Bretano JL, Antoine B, Ducrot H, Mery JP, Monteva H, Royer P. Nephrology. Volume 1. WB Saunders, Philadelphia, PA 1966.

10. Hodge HC, Stannard JN, Hursh JB, ed. Uranium, plutonium, and transplutonic elements. Springer Verlag, New York, NY 1973.

11. Iwao S, Tsychiya K, Sakurai H. Serum and urine beta-2-microglobulin among cadmium exposed workers. J Occup Med 22 (1980): 6, 399-402.

12. Lauwerys RR, Bernard A, Roels HA, Buchet JP, Viau C. Characterization of cadmium proteinuria in man and rat. Environ Health Perspect 54 (1984) 147-152.

13. Morrison D. Multivariate statistical methods. McGrawHill, New York, NY 1976.

14. National Institute for Occupational Safety and Health. Manual of analytic methods. Volume 1 (s 223). US De- partment of Health and Human Services, Centers for Disease Control, Cincinnati, OH 1977. (DHHS (NIOSH) publ no 77-157-A).

15. Nomiyama K, Yamamoto A, Sato C. Assay of urinary enzymes in toxic nephropathy. Toxicol Appl Pharmacol 27 (1974) 484-490.

16. Poulik M, Gold P. Beta-2-microglobulin: Methods and clinical applications. CRC Crit Rev Clin Lab Sci 10 (1979) 225-245.

17. Rothstein A, Berke $\mathbf{H}$. Aminoaciduria in uranium poisoning. J Pharmacol 96 (1949) 179-187.

18. Rowe JW, Andres R, Tobin JD, Norris AH, Shock NW. The effect of age on creatinine clearance in man: A cross-sectional and longitudinal study. J Gerontol 31 (1976) 155-163.

19. Schentag JJ, Plaut ME. Patterns of urinary beta-2-microglobulin excretion by patients treated with aminoglycosides. Kidney Int 17 (1980) 654-661.

20. Scriver CR, Rosenberg LE. Amino acid metabolism and its disorders. Saunders, Philadelphia, PA 1973.

21. Segal S. Disorders of renal amino acid transport. N Engl J Med 294 (1976) 19 1044-1051.

22. Spoor NL, Hursh JB. Protection criteria. In: Hodge HC, Stannard JN, Hursh JB, ed. Uranium, plutonium, and transplutonic elements. Springer-Verlag, New York, Heidelberg, Berlin 1973, pp 241-270.

23. Thun M, Stayner L, Brown D, Waxweiler R. Mining and deaths from chronic renal failure. Lancet 2 (1982) 606.

24. United States Army Material Development and Readiness Command. Handbook - Safety procedures for processing depleted uranium. US Army Materials and Mechanics Research Center, Watertown, MA 1978. (Darcom HDBK 385-1. 1-78).

25. United States Nuclear Regulatory Commission, Office of Standards Development. Standards for protection against radiation - Rules and regulations. Title 10 , Chapter 1, 20.1-20.21, Code of Federal RegulationsEnergy, Part 20. Washington, DC 1979.

26. United States Nuclear Regulatory Commission, Office of Standards Development. Bioassay at uranium mills. Regulatory Guide 8.22. Washington, DC 1978.

27. Voegtlin C, Hodge HC, ed. Pharmacology and toxicology of uranium compounds. Volumes $1-4$. McGraw Hill, New York, NY 1949.

28. Waxweiler R, Roscoe R, Archer V, Thun M, Wagoner J, Lundin F. Mortality follow-up through 1977 of the white underground uranium miner's cohort examined by the United States Public Health Service. In: Gomez $\mathrm{M}$, ed. Radiation hazards in mining: Control, measurements and medical aspects. American Institute of Mining, Metallurgical, and Petroleum Engineers, New York, NY 1981, pp 823-830.

Received for publication: 16 September 1982 